\title{
Andrzej Kątny
}

Rec.: Zbigniew Greń, Helena Krasowska, Słownik górali polskich na Bukowinie, Slawistyczny Ośrodek Wydawniczy, Warszawa 2008, 254 s.

Dziedzictwo kulturowe pogranicza, wyspy językowej czy też wybranej grupy ludności są dziś ważnym źródłem badań; recenzowana książka opisuje słownictwo niewielkiej grupy górali bukowińskich zamieszkałych pogranicze ukraińsko-rumuńskie. Już na samym początku należy zaznaczyć, że jest to pierwsza monografia zawierająca tak duży zbiór słownictwa tej malejącej polskiej grupy etnicznej na Bukowinie.

Bukowina leży na północno-wschodnim stoku Karpat. Do XVIII wieku należała do Hospodarstwa Mołdawskiego. W 1774 roku została odebrana Turcji przez Austrię i na jakiś czas włączona administracyjnie do Galicji. W drugiej połowie XIX wieku uzyskała rangę samodzielnego kraju koronnego ze stolicą w Czerniowcach. Po rozpadzie Austro-Węgier w 1918 roku znalazła się w obrębie państwa rumuńskiego. W 1944 roku została podzielona w wyniku zajęcia jej północnej części przez Związek Radziecki. Obecnie północna część Bukowiny należy do Ukrainy, a południowa znajduje się w granicach Rumunii ${ }^{1}$.

Ten krótki zarys historyczny wielokulturowego regionu odzwierciedlają zebrane w słowniku leksemy, które w znacznym stopniu noszą ślady kontaktów językowych (słowackich, niemieckich, ukraińskich, rumuńskich, rosyjskich).

${ }^{1}$ Por. H. Krasowska, Górale polscy na Bukowinie Karpackiej. Studium socjolingwistyczne i leksykalne, Warszawa 2006, s. 23 i n. 
Oprócz wstępu słownik zawiera rozdział Stan badań nad językiem Polaków bukowińskich (ze szczególnym uwzględnieniem górali) (s. 8-13). Krótki opis pozwala czytelnikowi na wgląd w literaturę przedmiotu. Język społeczności polskiej na terenie Rumunii (= Bukowina południowa) można podzielić (według badań Eleny Deboveanu i Stanisława Gogolewskiego) na cztery grupy: gwarę wsi Kaczyka, gwarę grupy górali bukowińskich, gwarę wsi Ruda oraz wsi Bulaj i Michoveny. Autorzy słownika stwierdzają (s. 13), iż na Bukowinie północnej (ukraińskiej) istnieje: „1. polszczyzna tzw. bukowińska, która jest kontynuacją polszczyzny południowo-wschodnich kresów; 2. gwara górali bukowińskich (o cechach odrębnych od p. 1.)".

Zbyt mało informacji opisowej znajdujemy na temat nieocenionego wydania dwóch tomów prac Kazimierza Feleszki ${ }^{2}$, brak także szerszego opisu wyników badań przeprowadzonych przez Helenę Krasowską ${ }^{3}$ i Eugeniusza Kłoska ${ }^{4}$, choć $\mathrm{w}$ wykazie skrótów pozycje te istnieją i są wykorzystywane w słowniku.

Materiał do słownika (por. Zakres eksploracji terenowej) był zbierany systematycznie w latach 2000-2005. Autorzy posługiwali się ankietą-kwestionariuszem własnego autorstwa, a także innymi kwestionariuszami dialektologicznymi, m.in. pod redakcją Witolda Doroszewskiego. Wykorzystali również materiały $\mathrm{z}$ bezpośrednich rozmów $\mathrm{z}$ informatorami, o luźnym charakterze, teksty z nagrań magnetofonowych i źródła drukowane w latach 1938-2006. Zamieszczone cytaty, które prezentują znaczenie apelatywów w rozmaitych kontekstach, ułatwiają zrozumienie odpowiednich haseł.

Komplementarność zastosowanej metody w prezentowaniu słownictwa górali bukowińskich prowadzi do interdyscyplinarnego spojrzenia na język ludowy i jego wymiar kulturowy. Zasady redakcyjne i spis skrótów (s. 17-24) pozwalają czytelnikowi na właściwe odczytanie haseł. Do walorów słownika zaliczyć również trzeba przejrzystość i konsekwencję w prezentacji poszczególnych haseł; nie każdy słownik takiego rodzaju jest tak przejrzysty.

Prezentowany słownik ma charakter dyferencyjny, to znaczy, iż rejestruje między innymi wyrazy: 1. różne treściowo i formalnie od ogólnopolskich; 2. różniące się od ogólnopolskiego znaczeniem, np. pończocha 'skarpeta';

${ }^{2}$ K. Feleszko, Bukowina moja miłość, t. 1: Język polski na Bukowinie Karpackiej do 1945 roku, red. A. Żor, Warszawa 2002; t. 2: Język polski na Bukowinie Karpackiej do 1945 roku. Słownik, red. E. Rzetelska-Feleszko, Warszawa 2003.

${ }^{3}$ Por. przyp. 1.

${ }^{4}$ Świadomość etniczna i kultura społeczności polskiej we wsiach Bukowiny rumuńskiej, Wrocław 2005. 
3. archaizmy w języku ogólnopolskim, a w gwarze nienacechowane, np. lico; 4. specyficzne dla gwary frazeologizmy, nieznane w języku ogólnopolskim nazwy analityczne - choroba $z$ cukru 'cukrzyca', wyrazy o specyficznej budowie słowotwórczej, jak również różniące się cechami gramatycznymi. Autorzy zdecydowali się włączyć do słownika wyrazy zgodne z ogólnopolskimi, jeśli są ważne pod względem kulturowym (to jedyne odstępstwo od zasad słownika dyferencyjnego).

Sam słownik jest bardzo obszerny (s. 25-254) i zawiera według moich szacunkowych obliczeń około trzech tysięcy haseł. W prezentacji słownictwa słusznie zastosowano zapis półfonetyczny, co pozwala na jego powszechniejszy odbiór i ułatwia percepcję poszczególnych leksemów. Warto zaznaczyć, że mowa górali bukowińskich została przedstawiona w szerszej perspektywie badawczej, która uwzględnia inne leksykony (np. Słownik huculski) i sytuuje ją w areale Karpat Wschodnich; posłużono się też innymi leksykonami, słownikami i atlasami, np. śląskim, bukowińskim, ukraińskim, rumuńskim, niemieckim, słowackim, polskim.

Do opracowania tego trudnego tematu badawczego powstał zespół autorski ${ }^{5}$ mający duże doświadczenie w eksploracji terenowej, interpretacji zebranego materiału, zespół o odpowiedniej kompetencji językowej, co ma istotny wpływ na jakość opisu haseł. Na tym etapie pracy autorzy „nie stawiają sobie za cel definitywnego rozstrzygania kierunków przepływów leksykalnych, gdyż Słownik nie ma charakteru diachronicznego. Przytaczany materiał porównawczy ma więc moc interpretacyjną przede wszystkim jako egzemplifikacja wewnętrznego zróżnicowania leksyki grupy góralskiej” (s. 18). Tak więc na przykład przy słowach zaklasyfikowanych jako pochodzące z języka niemieckiego (nie są to jednak germanizmy, gdyż nieustalony jest ostatni język, $\mathrm{z}$ którego pochodzi dany wyraz) podano $\mathrm{z}$ reguły podobnie brzmiące formy w języku ukraińskim, rosyjskim, rumuńskim, w gwarach cieszyńskich czy też górnośląskich ${ }^{6}$ abrykosa, abcug, borgować, bormaszyna, brajtrura, briftreger,

5 „Materiał ukraiński i rumuński wprowadziła Helena Krasowska, materiał śląski (z uwzględnieniem zróżnicowania wewnętrznego), czadecki, słowacki, czeski i ogólnopolski - Zbigniew Greń" (s. 19).

${ }^{6} \mathrm{~W}$ dalszych pracach wykorzystać będzie można na przykład następujące opracowania dotyczące zapożyczeń: M. Höfinghoff, Deutsche Entlehnungen im Ukrainischen an der Wende vom 19. zum 20. Jahrhundert. Bestand und Entwicklung bis zur Gegenwart, Wien 2006; M. Łaziński, Słownik zapożyczeń niemieckich w polszczyźnie, Warszawa 2008; T. Menzel, G. Hentschel, Wörterbuch der deutschen Lehnwörter im Teschener Dialekt des Polnischen, Oldenburg 2003; S. Newerkla, Sprachkontakte Deutsch-Tschechisch-Slowakisch, Frankfurt nad Menem 2004. 
brucak, cajgiem, curie, cwajrat, cwibak, cymra, deka, durślak, faska, fest, flanc, folga, frai, furt, futro, geszeft, gwer, krenwurst, lejbik, mantla, raszpla, rupsak, rychtować, sznycel, szimel, szipa, szmir, szparować, sztelwaga, sztraf, sztreka, szuber (i wiele innych). Wiele z podanych wyrazów występuje w języku potocznym, technolektach, gwarach ${ }^{7}$ lub regiolektach języka polskiego.

Postawiony cel opracowania udało się autorom osiągnąć w sposób znamienity. Zostały dobrane odpowiednie metody badawcze. Całość opracowania cechuje wysoki poziom naukowy. Słownik czyta się z ogromną przyjemnością dzięki zanurzeniu leksemów w zdaniach lub kontekstach pozwalających ogarnąć kulturę materialną i duchową górali. Recenzowany słownik stanowi dobrą bazę do dalszych badań nad językiem i kulturą górali bukowińskich.

Grono osób zainteresowanych tematyką bukowińską oczekuje na prezentację słownictwa tej grupy z tzw. Ziem Zachodnich, gdzie zamieszkuje spora część górali bukowińskich, którzy po 1946 roku znaleźli się na tym terenie. Interesujące byłoby porównanie słownictwa górali osiedlonych na tym obszarze. Zapewne w regionie czadeckim, skąd wywodzą się pierwotni użytkownicy danej gwary, istnieje również wiele nieznanych nam faktów językowych. Być może autorzy Słownika górali polskich na Bukowinie lub inni badacze pójdą tym tropem.

7 Por. np. Słownik gwary miejskiej Poznania, red. M. Gruch manowa, B. Walczak, Warszawa-Poznań 1997; Słownikgwar Ostródzkiego, Warmii i Mazur, oprac. przez Pracownię Słownika Gwar Ostródzkiego, Warmii i Mazur Zakładu Językoznawstwa w Warszawie, t. I-V, Wrocław-Warszawa-Kraków 1987-2006. 